$12-2012$

\title{
Searching for the right way to begin class, Part II
}

John D. Lawry

Fordham University, lawry@fordham.edu

Follow this and additional works at: https://fordham.bepress.com/psych_facultypubs

Part of the Educational Methods Commons, and the Psychology Commons

\section{Recommended Citation}

Lawry, John D., "Searching for the right way to begin class, Part II" (2012). Psychology Faculty Publications. 280.

https://fordham.bepress.com/psych_facultypubs/280

This Article is brought to you for free and open access by the Psychology at DigitalResearch@Fordham. It has been accepted for inclusion in

Psychology Faculty Publications by an authorized administrator of DigitalResearch@Fordham. For more information, please contact considine@fordham.edu. 


\section{Searching for the Right Way to Begin Class, Part II \\ John D. Lawry, Ph.D.}

For those relatively new to About Campus, "Part II" implies an original article that appeared on these pages in the Nov.-Dec. 2011/Vol. 15, No. 5 issue. That article, entitled, "Searching for the Right Way to Begin Class," described the various iterations of beginning class rituals I used over the years. Those rituals began with a prayer to the Holy Spirit as was required at the Catholic women's college, Marymount in Tarrytown, NY, in 1965 where I first taught out of graduate school. That was followed by a vacuum in the late 60 s \& 70 s, and then chanting $\mathrm{OM}$ in the 80 s and 90 s, to starting with a minute of silence in the last few years.

Upon re-reading "Searching for the Right Way to Begin Class," I realized that I did not capture the whole picture of the reality of beginning class or more accurately, when class actually begins. What brought it to my attention was a conversation I had years ago at a First Year Experience conference with a Concordia College (Lutheran) professor who was originally a fifth-grade teacher. She told me a fascinating story of how she used to hug her students at the beginning of the school day and again at the end. This caused no problem with either her students or their parents. However, her colleagues objected and complained to the principal, demanding that she stop. Their motives were not revealed. The principal informed her of her colleagues' objection and said he had no recourse but to ask that she stop. She told the principal that she could not in good conscience do so and volunteered to resign at the end of the year which she did. I inquired how she begins her classes at Concordia. She replied, "The same way." Incredulously, I asked about those who refuse her hugs. She told me that there 
were a few "tough guys" who did so at the beginning of the term but they quickly got in the hug line with everybody else within a couple of weeks.

I pondered the implications of this story for my teaching and the way I began my classes. Being a young male professor at a women's college at the time I immediately rejected the idea of hugging my students either before or after my classes. In fact, I developed a cautious policy of never touching students unless they touched me first, e.g., a spontaneous hug after a break or upon graduation, etc. But I recognized the value of touch as well as its hazards as an educational psychologist. Indeed, I learned that Waldorf school teachers shake the hands of their students at the beginning and end of the school day.

It wasn't until I read about "thin-slicing" in Blink by Malcolm Gladwell (2005) that I realized just how critical that first encounter (both initially and daily) with one's students actually is, whether tactile or otherwise. Gladwell defines thin-slicing as "the ability of our unconscious to find patterns in situations and behavior based on very narrow slices of experience" (p. 23). What made the concept particularly relevant was his reporting of the research of Nalini Ambady at Harvard at the time.

Ambady, a Harvard grad student, wanted to know how quickly and how accurately college students judge teachers. She began by showing students three ten-second videotapes of unknown faculty teaching and found that they had no difficulty in coming up with a rating of the teacher's effectiveness. She cut the clips to five seconds and eventually to two-seconds and found no difference in the ratings, "thin-slicing" indeed. More amazingly, Ambady compared her subjects' ratings of unknown faculty with the ratings of the professors' own students after a 
whole semester of classes and found that the ratings "were essentially the same." How could that be? Gladwell doesn't seem particularly surprised and concludes rather blandly, "That's the power of our adaptive unconscious" (p. 13).

I don't pretend to understand the phenomenon of "thin-slicing" in this case any better than Gladwell or perhaps even Ambady, though I have not had the opportunity to correspond with her. What I have learned is that my students are making judgments about me as soon as they walk in the door. (As an aside, I asked my grandson who is in kindergarten what he thought of his two teachers. He told me that he likes one but not the other. When I asked why not, he said, "Because she is mean." Apparently, students start making judgments about teachers as early as kindergarten.) Rather than try to impress my students, however I might try to do that, I decided that there are three things I can communicate both verbally and nonverbally. One, I try to create a welcoming classroom by at least smiling, introducing myself and asking them their name as they walk in. (This presumes of course that I am in the room before they are. When I first started teaching I was chronically late for my classes. After much soulsearching I realized it was motivated by fear. Now I try to be at least ten minutes early.) I sometimes also shake hands depending upon the vibe and my intuition. Two, I try to communicate that I like students in general and that, "I am going to like you if possible." Finally, I try to communicate that I love being a teacher and teaching what I teach, and since both are true it is not difficult.

Has my personal approach worked? I can only refer to my student evaluations (both anonymously and online now) as evidence and it has. Does that mean I am a better teacher 
now than before I developed this awareness? Certainly, I like to think so. I am very impressed with the social and emotional learning (SEL) movement and the research on the importance of the social and emotional environment in the classroom on student learning. I think Sylwester (1995) has it right: "Emotion drives attention, attention drives memory, and memory drives learning." If my classroom is perceived as welcoming and I am perceived as caring about students and what I teach, then that is the best I can do over and beyond my competence in the subject and ability to teach.

As an example of what such an approach can have on students, I would like to end with a rather extensive quote from a final self-evaluation paper of a very bright and articulate student whose name is Alyssa for a psychology course I taught several years ago called Perennial Quest (and who is now a college professor herself):

Reading over my journal in its entirety forces me to acknowledge the incredible growth I have experienced this semester as a result of Perennial Quest. As the journal indicates, and as my memory confirms, I began the course reluctant, or more appropriately, unable to share openly in the class discussions, or even to honestly express myself in the journal. This closed-ness made itself more apparent to me through the psychosomatic pain I experienced for the first half of the course. However, I decided to take a risk and allow myself to speak and write freely, as well as to listen and read closely. My journey of the semester presented itself in the journal. The end result is that right now I feel a tremendous sense of peace. In fact, the stomach pain, which has tormented me for 
years, has not been active in these last few weeks. I see this in itself as a clear sign of my personal growth.

I want to thank you for inviting me to make this journey and for these many gifts. I am so grateful that I could partake in this growth process and attain the delicious sense of peace. Thank you most especially for your openness, your nonjudgmental approach to your students, and for your love. Not only will I carry with me the lessons I have been granted during this semester, but I will also always remember you as a role model of healthy living, sincere interest in your work and your students, and the expression of genuine caring. Your living out of the words you impart to others, "Jai Bhagwan," (I honor the divine within you.) has inspired me to embrace the radical transformation that has begun within me in order to be able to, as I see you do, breathe the divine with such peace and such profound joy.

\section{Notes}

Gladwell, M. (2005). Blink: The Power of Thinking Without Thinking. New York, NY. Little Brown \& Co.

Sylwester, R. (1995). A Celebration of Neurons: An Educators Guide to the Human Brain. Alexandria, VA. Association for Supervision and Curriculum Development. 